\title{
An Appalling Scenario Growing Corruption and Its Obnoxious Impacts on Public Lives -With Special Reference of South-Asian Stigma
}

\author{
Atindra Dahal ${ }^{1}$ \\ ${ }^{1}$ Associate Professor, Kathmandu School of Law, Bhaktapur, Nepal \\ Correspondence: Atindra Dahal, Associate Professor, Kathmandu School of Law, Bhaktapur, Nepal.
}

Received: February 7, 2018

doi:10.11114/ijsss.v6i5.3237

\author{
Accepted: April 14, $2018 \quad$ Available online: April 24, 2018 \\ URL: https://doi.org/10.11114/ijsss.v6i5.3237
}

\begin{abstract}
Despite reiterated commitment from government and other stakeholders everywhere in the world, curbing corruption has been a seriously ticklish and almost next to an impossible effort, especially in south Asia. The failure to remarkably detain corruption not only left the countries financially crumbled but also transfigured them into zone of psychological and mental degradation followed with cultural erosion as well. This paper has revealed a surreal and sordid scene of growing corruption in south Asia and severe stigmatization of public life fashioned on ground of corruption. For the purpose, the author consulted plenty of relevant literature related to corruption theories, corruption realties and its suffocation to demonstrate the plague that the corruption has crowned to people. This research adopted a descriptive strategy with paradigm of interpretive analysis for building the proposition.
\end{abstract}

Keywords: corruption, south asia, human lives, development, prosperity

\section{Overview}

Corruption, despite being a most un-endearing and objectionable word, is very frequently echoed and faced, every day and everywhere. Unlike other ailments, which often weaken individual's health and stamina, corruption not only suffers the society then sabotages the psychology of people but also causes serious hampering on people's access over right to economic, social, developmental and cultural freedom too. It acts as one of serious setbacks and stumbling blocks to impede the possibility of economic empowerment, extension of development activities and assurance of cultural independence in people. The trend is growing everywhere but seem as popularly cultivated and showcased as an arch fashion in South-Asian sphere.

Therefore, this paper updates people with depth understating of pestilential and detrimental scene of corruption together with giving an undistorted information to non-south Asian readers, who might not have been reality updated or might have been misjudging south Asian reality. It may even assist the diplomatic missionaries, who are working with anti-corruption mission, to note the loopholes and devise their actions more fittingly to avert the pain. On this note, the article takes two different sections and that answer: a) why is corruption bad and b) how is that gowning in south Asia, respectively? Article is assumed to generate a proactive feeling on concerned agencies to work in detaining corruption, building better polices, encouraging public to raise voice and leading further discussion on curbing it in more modest manner.

\section{Corruption: Assimilation as an Unpleasant Happening [Literature Review]}

Though many forms of corruption can be noticed, only the misuse of entrusted power for private gain is key one in discussion and sight, these days. Many scholars (like Wei, 2000; Habib and Zurawicki, 2002; Zhao and et al., 2003; Voyer and Beamish, 2004; Ketkar and et al., 2005; Egger and Winner, 2006; and Das and DiRienzo, 2012) use the Corruption Perceptions Index (CPI)- published by the Transparency International- as a reliable tool to measure corruption. The very CPI index defines corruption as the misuse of public power for private benefit.

Indulging in corrupt nature is not mandatorily necessitated in interest of swelling monetary gains nonetheless the largest ratio undeniably falls on it. In addition, some people often love to misuse or underuse authorities for no reason then compel society to reel with further spins of bad luck and uncomely outcomes. Alike Rodrik (2002) believes on 'not having any unique and complete mapping' of corruption, any sort of evil-acts should be mandatorily subsumed as corruption on ground that they are against of ethics. Although only the ill-efforts to have unwise and un-allowed 
monitory gain is sole and single synonym of the corruption, such practices in non-governmental sector is largely subsided and paid an indifference at. Besides the ill-endeavors of civil service holders to amass additional monetary gains from service seekers or regular official duties, there are many other spheres where the corruption has to be noticed. Nonetheless, scholars like Gray and Kaufmann (1998), in a recent survey of about 150 high-level officials from 60 third world countries, infer that the respondents ranked public sector corruption as the most severe obstacle confronting their development process. Lederman et al (2001) call it as 'microeconomics of corruption' and Treisman (2000) too agrees on similar concept. Taghavi (2011) admits that pubic interests are directed towards private interests through corruption whereas Fjeldsted (2003) believes 'decentralization as tool to detain corruption'. Rauch \& Peter (2000) urge that proliferating mass attraction in civil service is because of vast possibilities of corruption there in. Thus, literature infallibly makes a hint that endless infatuation towards corruption is one of hallmarks in society, at present.

Therefore- still having only an incomplete assessment till now- corruption can be said of being one of bronchitis in almost every nation. To assure the condition, Quazi et al (2013) write "in the modern era, corruption has become prevalent and entrenched in many parts of the world, particularly in developing countries" (page: 87). The far-reaching backwardness and underdevelopment in almost nation is incontrovertibly underpinned with corruption. Lee's (2000) endeavour to change Singapore as 'first world oasis in Southeast Asia' also had high emphasis on corruption control.

Each country and government makes a note that fighting against corruption is one of the arch missions to be accomplished. Kunicova and Susan (2003) propose 'governments with more female participation in politics' as an instrumental tool to curb corruption to an extent like concept on 'Italy's clean hand operation' offered by Anderson and Tverdova (2003). Lu (2003) discloses a fact that their anti-corruption efforts were accompanied by new allegations of their own involvement in corruption. To paraphrase Uslaner (2004), it is quite naive to assume that a corruption can be exterminated by simply replacing its leaders or its law because other multifold mega efforts are always must to detain it as expected. On the top of dismay, even changes on leadership and laws also have had only a gross fiasco on mission in many nations.

Corruption is global phenomenon and a seriously cancerous endemic, especially in South-Asian region. Though Ketker et al (2005) talk about 'system of hisbah' as a very effective tool to detain economic corruption during medieval period in Islamic world, Ekelund et al (1999) and Langley (2009) highlight pervasively coevolved corrupt nature of churches. And the very same has been a nature throughout all the societies around the globe. The discussion on democracy without economic equality cum empowerment followed with rapid infrastructure-sufficiency will be a best meaninglessness and true hollow but corruption has caused multidimensional problem to these quests of globalized humankind on democracy, in all countries. Detaining corruption is not only placed as one of most top rating objectives to be stupendously surmounted by all governments but also has been envisioned as one of key and most measured parameters to reflect the efficiency and effectiveness of democracy. Besides improvement or impoverishment in system, corruption even adduces the leadership either as important or impotent in relation to its expected caliber. Rotberg (2004) regards corruption as one of the causes of governments being either better or bitter on public's mindset and understanding. But having success to control it is being a mirage therefore has not ceased to impede and aggressively mutilate the economic, developmental and social health of people. South Asian region places self atop of it. Agreeing to Sandholtz and Keotzle's (2000) view that less corrupt societies are with fewer problems, You \& Khagram (2004) stress then highlight negative effect of inequality on growth as one of the outrageous outcomes of corruption.

Conceding with Bardhan's (1997) inference that corruption can 'grease the wheels of commerce' in the presence of weak legal and regulatory frameworks, Houston (2007) found that corruption raises economic growth in countries that have weak legal frameworks but it has been severely harming mass people in south Asian zone. Referring Samad's (2008) note based on the World Bank's estimation that corruption in Pakistan is close to 10\% of GDP, Holm (2000) believes it to be an inherent nature to outshine if not to obstruct the pace of developing economics. Corruption of any type and nature harms people economically, socially, psychologically and in many other multidimensional ways. Even people infallibly and unswervingly object corruption as the root cause of backhandedness and underdevelopment of nation as well as very pauper and poor state of nation with similar impacts to the people. Das and DiRienzo (2012) analyzed corruption patterns in 42 countries in Africa and the Middle East using the Corruption Perceptions Index (CPI) to measure the perceived level of Corruption and noted that corruption heads to cause an all round problem.

Stiff economic growth is one of top citable hellish and harmful outcomes of corruption. The capital to be aggressively utilized for promotion of economic activities, hence economic status of people could be positively changed, will be at stagnation. On ground, the monitory strength of nation shall be embezzled for private gains of officials thus it lowers the economic growth and causes very nominal or deficient economic gains on side of people.

Such trend of corruption often and everywhere diverts the funds allocated for education, health and other developments to the favor to officials thus compels people to negotiate with no service or poor service. People can't enjoy the full 
sense of development. Shleifer and Vishny (1993) assume that the amount embezzled as corruption exceeds to tax of a country therefore Hope (2000) asserts that promotion of neo-patrimonialism became so pervasive around the world.

The compulsion to offer bribery leads the victims at peak of dissatisfaction. Even the service which was in his/her right makes extra cost thus an ingrained mistrust, hatred and objection towards officials get ever cultivated. Sometimes, it might cause further fights, confrontation and misbehaviors as well. Violent out-brusting of the victims might be further harmful for the both. Haque (2010) too feels that corruption in hospital is very common whereas Javaid (2010) claims that the loss made to the national exchequer due to corruption is over rupees 200 billion per annum. Corruption corrodes confidence and trust over the government thus, as Bowser (2001) manifests, mass theft of state's assets and massive tax evasion become largely unchecked and accrued. Doig and Theobald (2000) deem corruption colossally destructive rather than functional as it violates the fundamental principle of democracy.

Economic imbalances in society may be next apparent but appalling upshot that corruption begets. As the corrupt individuals amass plenty of property, it ensures economic inequality and unfair imbalances. Wei (2000) notes swift but severe shifts on the composition of capital flight nurtured by growing corruption. Kang (2002) observes secretly increasing mutual dependence between ruling elites and entrepreneurs because of practice of corruption. As the public service holders enjoy unfair and extra income from people seeking service, income inequality is another major jolt that corruption crowns a society. Myint (2000) writes, "as such, there is a tendency for wealth to be concentrated in the hands of a tiny minority of the population. Income distribution, therefore, becomes highly uneven" (page; 46) and discloses a sordid and sorry aspect of corruption.

Inefficient provision for service delivery and distortion of laws will be always on priority as that makes corruption take place. Marsida (2011) says that financial crisis of the late 1990s demonstrated that corruption has devastating effects on both political stability and economic prosperity and growth too. As corruption makes people amass a lot of properties, consumerist culture among those corrupt takes high speed. Since those people may pay any level of high price on goods and services and feel show off to pay high, it causes ballooning inflation with whooping side-effects to mass. Myint (2000) notes the very nature and writes, "corruption is closely associated with an unequal income distribution and concentration of wealth in the hands of a few, there emerges a distorted consumption pattern aimed at meeting the lifestyle of the new and extremely rich urban elite" (page; 47). Przeworski et al (2000) argue that corruption has vastly undermined the security of property right of public.

Since most of money allocated into development activities and maintenances of infrastructures are embezzled, the poor level development and maintenance are common. Rest of sum will be diverted for private gains. Wedeman (2002) believes that South-Asian paradox of weak nation and rich people is totally a construct of capacious corruptionprevailing in the region.

Political unrest is often a consequence of corruption; and way to detain it is another phenomenon that restricts and discards the time and efforts to be allocated on development. Munck and Verkuilen (2002) regard that one of the indicators to measure the efficiency and effectiveness of democracy is its capacity to curb corruption. Unlike hints of domestic anxieties and stress by above cited authors, Khan and Jomo (2000) consider corruption as 'alluvial for promotion of foreign investment then interference' ahead.

Corrupt countries have poor social image in international arena. Other countries make a look with disrespect and domination hence people of high corruption index nation ought to reel under psychological stress and volatility. To confirm it, Myint (2000) writes, "the rising trend in the use of corruption as a tool to discredit political opponents, the media's preoccupation with it as a highly marketable commodity, and the general public's fascination with seeing prominent personalities in embarrassing situations have brought scandalous and corrupt behaviour, a common human frailty, into the limelight of international attention" (page; 33). Further, Campos (2002) deems strict detention from governance- the proponents of 'good governance'- only as a key tool to outsmart corruption.

Lack of service and justice is equally common because of corruption. Often it goes so since it is totally unjust to pay unsolicited and unneeded money for service. Poor service delivery may be next outcome of corruption since incapable and less meretricious people might be selected in the job backed with a sea long influence of corruption. A survey of six South Asian countries found that two in three people, who deal with public services, said that they paid bribes (Transparency International Secretariat, 2012). Based on feeling and fact of such discouraging scenario, Nye (1967) feels corruption as an alternative channel to influence the private sectors.

On ground that corruption influences medical and driving license certification, quacks might cause end of patients' lives followed with that unfair distribution of license might cause riders to increase the volume of road accidents. In cases corruption takes speedy rife, people cease to have respect for rulers. Mass anathema and disrespect will be usual and everyone's cup of tea. 
Decreased investment and delayed growth, as an upshot of various administrative hassles and bureaucratic noncooperation, will be quite common since corruption definitely discourages the pool of prospective investors. Tanzi and Davoodi (1997) found that corruption reduces productivity of public investment and quality of infrastructure; and Habib and Zurawicki (2002) found that corruption creates market distortions by providing corrupt firms preferential access over lucrative markets. Babb (2002) infers a conclusion that strict actions and mechanism against corruption has caused significant positive growth on economic and social development in Countries in the large East Asian newly industrializing economies (LEANICS) category like China, Indonesia, South Korea, Thailand and Japan. Li et al (2000) believe that corruption reduces investment and slows economic growth and same is happening in South-Asian region whereas $\mathrm{Wu}$ (2006) believes that national and cross-border investment is being obnoxiously eroded because of corruption. Corruption fuels inequality and injustice then undermines stability, especially in the world's most vulnerable regions thus takes people at restlessness and pool of pains; and South Asia has been an epitome of it. The way how south Asia is being mercilessly marred with corruption is enumerated hence-so-forth.

\section{Sordid South-Asian Situation [Discussion of Real Situation]}

Rajak (2013) talks about the major 11 types of corruption scamps, ranging from 4000 corers to 186000 corers in monetary values, taking place in India.. He further presents that $90 \%$ demand for bribe in January 2009 was made from government officials, of which over $65 \%$ was for avoiding harassment, $50 \%$ bribery was for timely delivery of services. Nonetheless, the individuals were already entitled for such rights sans any further cost and delay. Apart from it, black money is assumed of destroying the Indian democratic system; and for the same reason, the debate of Lokpal bill was high at a time. A report titled Bribery and Corruption: Ground Reality in India (2014) claims that the corruption has largely sabotaged the economic growth. Annually, $0.5 \%$ loss on GDP of India is incurred because of corruption as that makes loss of 364 billion, which could amount a lot for changes and succeed many of development projects. Kundu (2015) claims that BPL householders paid annually total 8830 million as bribe and most of corruption practices took places in the departments of police, land record and registration, and housing. A report titled Indian Corruption Study (2010) claims that the largest share of total bribery falls into delivery of public services, hospitals, schools and water supply department therefore those cause poor or delayed services to people. Bardhan (2005) argues that higher bribes are discouraging productive investments and talks about bureaucratic and political corruption as well whereas Basu (2007) calls political bribes as harassment bribes. Das-Gupta (2007) categorizes bribes into 2 groups as coercive bribes and voluntary bribes but both are pernicious for people hence subsequently he argues that people in India have multi-fold suffered because of such bribes. Besides Quah's (2008) note on voluntary bribes as an unethical as well as an equally serious problem for society, Abbink et al (2014), using a lab experiment among students, found that all sorts of corruptions as serious problem in development of India.

A study from Banerjee et al (2007) find 27 percent teachers absent in Jaunpur district in Uttar Pradesh and observe 54 percent health care workers absent in Udaipur in Rajasthan. Such negligence of officials has terribly affected the human rights and people's access to facility. And Bhavnani (2012) too notes that 4 to 9 percent of election winners do it on misuse of money therefore, after victory, those people try to compensate money through any of unfair means and corruption instead of serving people up to the need. Health system is increasingly difficult to attract nurses to work at rural outposts because of thin chance for corruption as Dhaliwal and Hanna (2015) point out. Laffont (2006) finds 'unfortunate juncture of a heavily regulated economy' and that has resulted officials generally richer than beneficiaries and taxpayers as Olken's (2006) studies suggest. The reason of officials being rich is because that they enjoy bribery a lot. In sequel, such misconduct not only imbalances people in terms of their financial status but also degrades the quality of service they have to owe. It leads people into deprivation from quality service then drives into psychological unrest too. It is going so in India.

The rampant corruption from political leaders in Nepal is common for long. Otherwise it would not be possible to earn multi-million rupees within a few years of holding key bureaucratic post or being a political authority. Pyakuryal's (2000) norm of 'Pajero culture' and remarks as that the 'lawmakers were sold and bought for millions of rupees further' makes a clear hint of ballooning corruption on top level. Sissener (2001) says that service seekers get direct observable activities of corruptions in offices like Land Taxation Office, Tax Office, Company Registrar's Office, International Borders, Educational Institutions, and even in Hospitals. To further exhibit the deteriorating situation, FORHID's (2010) report concerns for various cases of pardons, amnesty and withdrawals on many corrupt people and murderer that have caused serious questions on fair justice. The rapid increase of Corruption cases in Nepal is shown on Dix's (2011) studies as that was 564 in 1990 but reached to 4295 in 2010 AD. Chiefly, the 11 types of corruption offences from giving and taking grafts to being an accomplice to corrupt activities are noticed. Many cases are reported into courts and those are wide in natures from fake education certificate submission in job or in promotion to embezzlement of forest resources. Military expenditures constitute $12 \%$ of Nepal's national budget and there is voice for vapid corruption. The Army does not have economic power per se but its welfare fund has now reached roughly 16 
billion rupees. Dahal (2017) talks a lot of corruption scandals in various districts like Dhanusha, Sindhupalanchok and Shankhuwasbha of Nepal as an outcome of absence of local representatives in nation for last 15 years. Govinda KC has again and again been into fast-to-death hunger strike against of corruptions in health sectors. In last few years, CIAA arrested many people while indulging the grafts and taking bribe, on the spot and red-hand. Most of those are officials from immigrations, land measurement and so on. Besides, noting many forms of corruptions into various municipalities and local level bodies, Shrestha (2007) remarks that 10 per cent commission is customary in many cases. Corrupt officials often practice better or bitter drinking water supply on the possibility of corruption. Electricity authority makes meter read smaller units. Municipal gives buildings in contracts in less money and enjoy bribes in project incurring. Unseen partnership between service providers and contractors is rife. Fake bills for maintenance, fuel and others are usual sights. Authorities fail to monitor the quality of meat, vegetable and other items thus poor items are sold to public. Development projects are delayed, deteriorated and decayed causing a big harm against public right of safe and quality infrastructure. Such all and ill activities have negatively impacted the life of people, degraded the quality of living and obstructed the fair justice as well as regular progress and development of society.

Shepler (2015) finds poor governance and extreme corruption as the arch problem in all areas of Afghanistan's administration whereas Walsh (2014) notes 'corruption as system' and remarks that more than half of Afghan annual custom's revenue is being lost to graft. Studies from Torabi (2012) finds that all service seekers are forced to pay a bribe thus normal people are harmed economically a lot. With an empirical standpoint, Ahmed and Walsh (2014) infallibly argue that Afghan citizens want to see government officials take visible actions to crack down on corruption at all levels because they find corruption rife and pubics are largely affected because of it. Shalizi (2014) accuses the political elites of diverting billions of foreign aid, in dollars, and investment to themselves and their allies, resulting in a number of high-profile scandals. And it has heavily impeded the development and well operation of society. Goldstein (2015) remarks corruption as key factor undermining developmental progress and morale at the unit level and Noorami (2015) deciphers that Afghanistan's vast mineral wealth is estimated at nearly $\$ 1$ trillion but remains largely unexploited in cost of corruption. Besides, the development status of people and having access to better physical facilities like transport, health education and others is seriously jeopardized.

A report titled Business Anti-corruption Portal (2012) draws a conclusion that business executives perceive corruption as the second most significant obstacles to doing business in Bangladesh. Thus it has even crumbled and shackled the business as well. Businessmen there are asked graft from registration to many procedural tasks thus it discourages doing business. Syful (2012) notes that the depraved bankers offer loans to businessmen supported by political leaders sans the needed due diligence, drying up the system and slowing down the country's economic growth. A study from Colin (2009) exhibits profound corruption in the health sector and regards that as reflection of general governance problems in Bangladesh's public sector. Referring to the World Bank's reporting, Shakeel (2010) deems many practices such as short bidding periods, poor advertising, nondisclosure of selection criteria, poor specifications, negotiations with bidders and rebidding without adequate justification create opportunities for corruption and bribery therefore officials intentionally do it in interest of having that illicit and illegitimate gains. Farzana (2014) believes that police officers have very low salaries and difficult working conditions thus they try to get loopholes of collecting such benefits through bribery. Michael (2010) deems corruption and bribery as key causes that the most vulnerable households to be exposed to the risk of not being able to pay for food, of being deprived of medical facilities, of losing their business and of not being able to put their children in school consequently resulting in violation of rules of public office motivated by private gain as Kurer (2005) claims.

Referring a recent improvement on anti-corruption praxis in Bhutan as the arch reason, Mayumi (2011) notes a notable improvement in governance and quality service delivery together with significant fall on pattern of corruption credited to an e-registration system. Bhutan therefore succeeded to place self high in the pace of positive development and progressive changes. As per the latest report, Bhutan scored 63.8 percentile rank where as many other nations of similar income level only have earned roughly around 25 percentile rank. Such remarkable change and difference is credited to the stable government in Bhutan thus she has accelerated the vibes of progress.

Assimilating it as an aftermath of such accomplishment, Alkire (2011) has argued that Bhutan sojourned on considerable decline in multi dimensional poverty from 2007 to 12 AD. Being too close to the inference, Ura et al (2012) do agree that the arch reason of competitive progress of Bhutan was stability induced political meritocracy and efforts in curbing the corruption.

Sinah (2001), on appraisal of Bhutan's king, writes, "he may be included among those few charismatic leaders of the human race whose life and death are the immortal saga linked intimately with the destiny of a people (page; 52)." Mathou (2000) notes that Bhutan's politics is quite stable and indifferent towards the robustly sweeping changes of the world in second half of the twenty century thus none of either capitalism or socialism or communism or liberalism enveloped Bhutanese polity and political culture in the sphere of their influence. Wangchuk (2004) understands it as 
Bhutan's peculiar craft to adapt to the rapidly fluctuating political praxis whereas Winderl (2004) feels Bhutan strongly succeeding in course of being better nation with overall progress sufficiently underscored and underpinned through adequately appreciative stance to detain corruption unlike other nations of region.

To lay stress on the deteriorating situation in Maldives, Nagy (2005) highlights the profound risk among people, who are surviving on agriculture and fishing, because of instability and changes in plans as all of these are easing and leading to the corruption. So is Neville's (2007) observation. Wadhwa (2000) notes considerable rise on public trust and fidelity when corruption goes controlled. UNDP's (2010) report unmasks civil society too as inert and inept to voice against corruption in solid manner therefore public has commenced harboring deep hatred and opprobrium against political mechanism. Reports by MOHA, FJS, HRCM and other concerned agencies (2010) rate corruption as first setback for all ethical and expected practices from employment to corporate social responsibilities. Even high bills are made for the small task as well. Lack of social audit for many such programmes unbendingly encourages impunity and anarchism. De Kruijk and Rutten (2008) find serious corruption on Tsunami management as well whereas Leusink (2006) has revealed the vulnerabilities of suffered is further augmented and aggravated because of corruption.

In an article related to corruption and its deep impacts on good governance in Pakistan, Javaid (2010) statistically claims loss of 200 billion per annum because of corruption and at the same time finds such mega corruption basically in development projects which have direct impact on lives of normal people. Bribes have been main attraction and inspiration for those who love government jobs as Yolles (2008) observes 'High inequality' (page; 88) as the outrageous outcome and pestilential impact of heavy corruption. Chene (2008) feels Pakistan severely paralyzed and swiftly plundered with profundity of both petty and policy corruptions, respectively. This endemic has enervated and etiolated all sectors over the nation. Widespread financial and political corruption, nepotism, and misuse of power are rampant. Bhidal (2011) notes dismal and deteriorating service delivery in education because of corruption since the funds allocated for improvement of children are all embezzled. Guess (2005) urges for revival of local government system so that it can ensure efficient and efficacious methods of social accountability. Khan (2001) lays focus on structural change and reforms over 18 types of monetary corruption practices and 13 sorts of non-monetary corruption practices as categorized by Nishtar (2007). Among all, oversupply of payment for collecting gains from it is most frequently reoccurring plight. Abbasi (2011) concludes that very practice made Pakistan extremely inefficient in nation building whereas Arif et al (2010), based on survey to 4002 households, make a synopsis that there is complete ceasing or serious erosion on quality of basic facilities because of corruption.

In case of Sri Lanka, Gunawardena (2010) notes development being heavily downsized in scale and deteriorated in quality followed with weakening livelihoods, evil-decision making and other illicit and impolitic manners as an outcome of corruption. Hettige (2003) brings an empirical analysis of severely poor condition of road, health posts and schools because of corruption prevailed there in. Bigdon and Gunasegara (2003) observe reflection on conflict among local government and its authority for corruption and embezzling of funds alike Khan (1998) explains erosion on social ethics and moral values. To further support Chan's (1998) argument as that the moral damage is most irreparable and chronically alarming outcome, Begovic (2003) points out the extreme violation of laws because of corruption therefore having either stagnant or sluggish growth grate. Barash et al's (2001) argument as 'low level of trust and high level of paranoia' among people and development agents is a further turmoil. Goodhand (2001) deems corruption as an outlandish aftermath of Complex Political Emergency, which, in words of Klem (2002), is a key enemy for development whereas Martin (2002) calls it bronchitis of development as administration has failed to remain accountable. Wickramasinghe (2001) believes an active participation and proactive role of 25000 NGOs and INGOs in promotion of corruption alike the finding of Samarasinghe (2002), who deems poor money laundering as an outcome of corruption. These all activities have enormously hampered the lives of people and tremendously battered the development possibilities.

Even the latest corruption perception index 2017 finds all south Asian nations, except Bhutan, having deplorably a high level of corruption. Afghanistan stands as lead one in the most corrupt countries in entire world with almost similar status of Nepal, Pakistan, Bangladesh, India, Sri-Lanka and Maldives. These all nations have scored less than 40 out of 100. Similarly, many south Asian politicians and industrialists were listed in panama paper, leaked last year, and it shows that they are corrupt thus are trying to hide the money gained through an unfair means. Only from Nepal, 13 people were named and they were charged of evading a heavy tax. India, from this region, had approximately 500 people in the list. They all are of high profile now and of higher corruption in involvement which caused them amass that much of money.

\section{Conclusion [Implication and Future Direction]}

Reading over the south Asian situation, it is an undeniable inference that corruption has multidimensional negative impacts and overall suffocation cum losses to the nation and people. The sweeping corruption trend in this region has 
largely curtailed public's opportunity to enjoy rights to development and has rescinded the pursuit of it. All things from public's day to day life to nations' smooth course of development are vastly hampered and ravaged because of corruption. South Asian scenario infallibly exhibits the pathetic human lives because of massive corruption fashioned in this region. Hence, in order to have an expected course of progress that people aim and leadership promises, detaining corruption should be a first and foremost focus. All concerned stakeholders should build strong and ruthless anticorruption drive to take it in control. Further researches should explore the possible solutions to hit on this sorry state cum vulnerability of south Asian region.

\section{References}

Abbasi, A. (2011). Public Sector Governance in Pakistan: Board of Investment (BOI). International Journal of Politics and Good Governance, 2(2).

Abbink, K., Utteeyo, D., Lata, G., \& Tarun, J. (2014). Letting the Briber Go Free: An Experiment on Mitigating Harassment Bribes. Journal of Public Economics, 111(March), 17-28.

https://doi.org/10.1016/j.jpubeco.2013.12.012

Ahmed, A., \& Walsh, D. (2014). New Afghan Leader, Putting Focus on Graft, Revives Bank Fraud Inquiry. The New York Times, October 1, 2014, available at http://www.nytimes.com/2014/10/02/world/asia/afghanistan-presidentcorruption- investigation.html

Alkire, S. (2011). A National MPI for Bhutan: Three Trial Measures. Oxford: Oxford Poverty and Human Development Initiatives.

Anderson, C., \& Tverdova, Y. (2003). Corruption, Political Allegiances, and Attitudes towards Government in Contemporary Democracies. American Journal of Political Science, 47(1), 91-109. https://doi.org/10.1111/1540-5907.00007

Arif, S., William, C., Andrew, G., \& Ritu, N. S. (2010). The Local Government System in Pakistan: Citizens Perceptions and Preferences. IDG Working Paper No. 2010-02.

Babb, J. (2002). Political Business, and the Inescapable Web of Structural Corruption in Japan. Political Business in East Asia. Edited By E. T. Gomez. London: Routledge, 324-338. https://doi.org/10.4324/9780203166338_chapter_10

Banerjee, A. V., Shawn, C., Esther, D., \& Leigh, L. (2007). Remedying Education: Evidence from Two Randomized Experiments in India. Quarterly Journal of Economics, 122(3), 1235-1264. https://doi.org/10.1162/qjec.122.3.1235

Barash, A., Nancy, H., \& Ginny, N. (2001). Accountability and Transparency - The Sri Lankan Case Study. Colombo: Consortium of Humanitarian Agencies.

Bardhan, P. (1997). Corruption and Development: A Review of Issues. Journal of Economic Literature, 35(3), 1320-1346.

Bardhan, P. (2005). The Economist's Approach to the Problem of Corruption. World Development, 34(2).

Basu, K. (2007). Why, for a Class of Bribes, the Act of Giving a Bribe should be Treated as Legal. India: Ministry of Finance, Govt. of India.

Begovic, B. (2003). Corruption: Concepts, Types, Causes and Consequences. Documento, 26(111), 2-8.

Bhavnani, R. (2012). Using Asset Disclosures to Study Politicians' Rents: An Application to India. Paper presented at World Bank Annual Bank Conference on Development Economics, Washington, DC.

Bhidal, F. Y. (2011). Equitable Education in Pakistan: Addressing Gender and Rural-Urban Gaps in Lower Secondary Education. Sustainable Development Policy Institute (SDPI).

Bigdon, C., \& Gunasegara, N. (2003). Empirical Study on Local Governance in Three Regions of Sri Lanka: Framework Analysis and Methodology. Local Government and Conflict Management in Sri Lanka. Edited by S.T. Hettige. Development Studies Institute of the University of Colombo.

Bowser, D. (2001). Corruption, Trust, and the Danger to Democratization in the Former Soviet Union. The Transition: Essays on Post-communism. Edited by Lovell David. London: Ashgate Publishers.

Campos, J. E. (2002). Corruption: The Boom and Bust of East Asia. Manila, Philippines: Ateneo De Manila University Press.

Chan, T. (1998). Corruption Prevention- the Hong Kong experience. $113^{\text {th }}$ International Training Course Visiting Experts' Papers. Hong Kong, 365-370.

Chene, M. (2008). Overview of Corruption in Pakistan. Retrieved May 17, 2010, from http://www.u4.no/helpdesk/helpdesk/query.cfm?id=174 
Colin, K. (2009). Dealing with Sectoral Corruption in Bangladesh: Developing Citizen Involvement. University of Ulster.

Dahal, A. (2017). Prathamikatama Sthaniya Chunab, Priority on Local Election (Trans). Gorkhapatra. Edited by Shushil Koirala. Nepal: Gorkhapatra Corporation., February 26, Page 6, Opinion.

Das, J., \& DiRienzo, C. (2012). Spatial Decay of Corruption in Africa and the Middle East. Economic Papers, 31(4), 508-514. https://doi.org/10.1111/1759-3441.12008

Das-Gupta, A. (2007). Corruption. Oxford Companion to Economics in India. Edited by K, Basu. New Delhi: Oxford University Press.

De Kruijk, H., \& Rutten, M. (2008). Tsunami Impact on Poverty Dynamics in the Maldives. Discussion Paper. Rotterdam: Erasmus University.

Dhaliwal, I., \& Hanna, R. (2014). Deal with the Devil? The Success and Limitations of Bureaucratic Reform in India. Mimeo. Harvard Kennedy School.

Dix, S. (2011). Corruption and Anti-Corruption in Nepal Lessons Learned and Possible Future Initiatives. Oslo, Norway: 2011.

Doig, A., \& Theobald, R. (Edited). (2000). Corruption and Democratization. London: Frank Cass.

Egger, P., \& Winner, H. (2006). How Corruption Influences Foreign Direct Investment: A Panel Data Study.” Economic Development and Cultural Change, 54(2), 459-486. https://doi.org/10.1086/497010

Ekelund, R. B., R. D. Tollison, G. M. Anderson, R. F. Hebert \& A. B. Davidson. (1999). Sacred Trust: The Medieval Church as an Economic Firm. UK: Oxford University Press.

Farzana, N. (2014). Overview of Corruption in the Justice Sector in Bangladesh. U4: Expert Answer.

Fjeldsted, O. (2003). Decentralization and Corruption: A Review of the Literature. Norway: U4 Report, Chr. Michelsen Institute, Bergen.

Goldstein, J. (2015). Police Force in Afghanistan is Studied for Ties to the Taliban. The New York Times. https://doi.org/10.1111/j.1540-6210.2005.00446.x

Goodhand, J. (2001). Conflict Assessments: Aid, Conflict and Peace Building in Sri Lanka. London: Centre for Defence Studies, King's College.

Gray, C. W., \& Kaufmann, D. (1998). Corruption and Development. Finance and Development, 35(1), 7. IMF/World Bank.

Guess, G. M. (2005). Comparative Decentralization Lessons from Pakistan, Indonesia, and the Philippines. Public

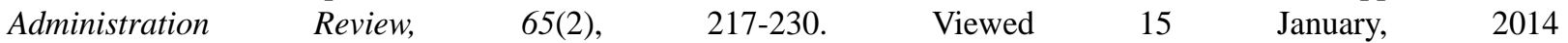
http://onlinelibrary.wiley.com/doi/10.1111/j.1540-6210.2005.00446.x/abstract

Gunawardena, A. (2010). Local Government under Devolution. Twenty Two Years of Devolution: An Evaluation of the Working of Provincial Council in Sri Lanka. Edited by Amarasinghe, Y. R. et al. Rajagiriya: Institute for Constitutional Study.

Habib, M., \& Zurawicki, L. (2002). Corruption and Foreign Direct Investment. Journal of International Business Studies, 33(2), 291-307. https://doi.org/10.1057/palgrave.jibs.8491017

Haque, A. U. (2010). Corruption in the Government Hospitals. International Journal of Pathology, 8(2), 73-81.

Hettige, S. T. (2003). Local Government in the Central Province: Ambagamuwa Pradeshiya Sabha. Local Government and Conflict Management in Sri Lanka. Edited by S.T. Hettige. Development Studies Institute of the University of Colombo.

Holm, J. D. (2000). Curbing Corruption through Democratic Accountability: Lessons from Botswana. Corruption and Development in Africa. Edited by K. R. Sr. Hope \& B. Chikulo. London: Palgrave, 288-304. https://doi.org/10.1057/9780333982440_16

Hope, K. R. (2000). Corruption and Development in Africa. Corruption and Development in Africa. Edited by K. R. Sr. Hope \& B. Chikulo. London: Palgrave, 17-39.

Houston, D. (2007). Can Corruption Ever Improve an Economy? Cato Journal, 27(3), 325-342.

Javaid, U. (2010). Corruption and Its Deep Impact on Good Governance in Pakistan. Pakistan Economic and Social Review, 48(1), 123-134.

Kang, D. (2002). Bad Loans to Good Friends: Money Politics and the Developmental State in South Korea. International 
Organization, 56(1), 177-207. https://doi.org/10.1162/002081802753485179

Ketkar, K., Murtuza, A., \& Ketkar, S. (2005). Impact of Corruption of Foreign Direct Investment and Tax Revenues. Journal of Public Budgeting Accounting and Financial Management, 17(3), 313-340. https://doi.org/10.1108/JPBAFM-17-03-2005-B004

Khan, M. H. (1998). Patron-client Networks and the Economic Effects of Corruption in Asia. European Journal of Development Research, 10(1), 15-39. https://doi.org/10.1080/09578819808426700

Khan, M. H., \& Jomo, K. S. (Edited.). (2000). Rents, Rentseeking and Economic Development. Cambridge: Cambridge University Press. https://doi.org/10.1017/CBO9781139085052

Khan, S. R. (2001). Promoting Democratic Governance: The Case of Pakistan. The European Journal of Development Research, 13(2), 81-96. https://doi.org/10.1080/09578810108426795

Klem, B. (2002). Sharing Studies on Development and Conflict in Sri Lanka: Synthesis of Eight Studies. The Hague: Clingendael, Conflict Research Unit.

Kundu, M. (2015). Some Aspects of Corruption in India in 21st Century. International Journal of Scientific and Research Publications, 5(12), India. ISSN 2250-3153. Retrieved at: www.ijsrp.org

Kunicova, J., \& Susan, R. A. (2003). Electoral Rules as Constraints on Corruption. New Haven CT: Yale University Department of Political Science.

Kurer, O. (2005). Corruption: An Alternative Approach to its Definition and Measurement. Political Studies, 53, 222-239. https://doi.org/10.1111/j.1467-9248.2005.00525.x

Laffont, J. J. (2006). Corruption and Development. Understanding Poverty. Edited by Abhijit V. Banerjee, Roland Benabou, and Dilip Mookherjee. Oxford: Oxford University Press, 2006.

Langley, S. (2009). An Economic Analysis of the Early Medieval Church: Technology, Consanguinity, and the Sale of Marriage Dispensations. LAP, Lambert Academic Publishing.

Lederman, D., Loayza, N., \& Soares, R. R. (2001). Accountability and Corruption: Political Institutions Matter. Mimeo. Washington, DC: World Bank. https://doi.org/10.1596/1813-9450-2708

Lee, K. Y. (2000). From Third World to First. New York: Harper Collins Publishers.

Leusink, J. (2006). Waterproof? A Post-tsunami Vulnerability Study of the Maldives. Master's Thesis. Rotterdam: Erasmus School of Economics, Erasmus University.

Li, H., Xu, L. C., \& Zou, H. (2000). Corruption, Income Distribution and Growth. Economics and Politics, 12(2), 155-182. https://doi.org/10.1111/1468-0343.00073

Lu, X. (2003). East Asia. Global Corruption Report 2003. Transparency Inter-National.

Marsida, A. (2011). Political Transition, Corruption in new Democracies- Special Case. International Journal of Economic Research, Vol. 2, No 3. Albania. P+111-124, May -June 2011, online@www.ijeronline.com

Martin, I. (2002). Human Rights in Sri Lanka after Ceasefire: Report of the International Working Group on Sri Lanka. London: International Working Group.

Mathou, T. (2000). The Politics of Bhutan: Change in Continuity. Journal of Bhutan Studies, 2(2).

Mayumi, M. (2011). Measuring Impacts of E-government Support in Least Developed Countries: A Case Study of the Vehicle Registration Service in Bhutan. Bhutan: Information Technology for Development, 17(2), 133-152. https://doi.org/10.1080/02681102.2010.537251

Michael, S. (2010). A Side Effect of Corruption in Bangladesh. Space for Transparency, http://blog.transparency.org/2010/05/07/a-side-effect-ofcorruption- in-bangladesh

Munck, G. L., \& Verkuilen, J. (2002). Conceptualizing and Measuring Democracy. Comparative Political Studies, 35(1), 5-34. https://doi.org/10.1177/001041400203500101

Myint, U. ( 2000). Corruption: Causes, Consequences and Cures. Asia-Pacific Development Journal, 7(2), 33-57.

Nagy, J. (2005). Maldives: Opportunities for Risk Management in Agriculture and Fisheries. Draft discussion paper. Rome: FAO, November.

Neville, A. (2007). Dhivehi Raajje: A Portrait of Maldives. Male: Seven Holidays Publishing.

Nishtar, S. (2007). Corruption in the Health Sector in Pakistan. Heart File and Transparency International.

Noorami, J. (2015). “Afghanistan's Emerging Mining Oligarchy.” (USIP, 2015) available at 
http://www.usip.org/sites/default/files/SR358-Afghanistan-s-Emerging-Mining-Oligarchy.pdf

Nye, J. S. (1967). Corruption and Political Development: A Cost-Benefit Analysis. American Political Science Review, 61, 417-427. https://doi.org/10.2307/1953254

Olken, B. A. (2006). Corruption and the Costs of Redistribution: Micro Evidence from Indonesia. Journal of Public Economics, 90(4-5), 853-870. https://doi.org/10.1016/j.jpubeco.2005.05.004

Przeworski, A., Alvarez, M. E., Cheibub, J. A., \& Limongi, F. (2000). Democracy and Development: Political Institutions and Well-Being in the World, 1950-1990. Cambridge: Cambridge University Press. https://doi.org/10.1017/CBO9780511804946

Pyakuryal, K. N. (2000). Restoration of Democracy and People's Empowerment in Nepal. Occasional Papers in Sociology and Anthropology, Vol. VI (15-25). Kirtipur, Nepal: Central Department of Sociology and Anthropology, Tribhuvan University.

Quah, Jon. S. T. (2008). Curbing Corruption in India: An Impossible Dream? Asian Journal of Political Science, 16(3). https://doi.org/10.1080/02185370802504266

Quazi, R., Sonja, L., \& Ada, T. (2013). Corruption Contagion in South Asia and East Asia: An Econometric Study. International Journal of Developing Societies, 2(3), 87-95.

Rajak, J. S. (2013). Corruption in India: Nature, Causes, Consequences and Cure. IOSR Journal of Humanities and Social Science (IOSR-JHSS.): Volume 18, Issue 5, P+ 20-24 e-ISSN: 2279-0837, p-ISSN: 2279-0845.

Rauch, J. E., \& Peter, B. E. (2000). Bureaucratic Structure and Bureaucratic Performance in Less Developed Countries. Journal of Public Economics, 75, 49-71. https://doi.org/10.1016/S0047-2727(99)00044-4

Rodrik, D. (2002). Feasible Globalizations. Mimeo. Cambridge, MA: Harvard University. https://doi.org/10.3386/w9129

Rotberg, R. (Edited). (2004). When States Fail: Causes and Consequences. Princeton NJ: Princeton University Press.

Samad, S. (2008). Combating Corruption: The Case of the National Accountability Bureau, Pakistan. JOAAG, 3(1).

Samarasinghe, S. W. R. D. A. (2002). Money Laundering: The Global Phenomenon and the Sri Lankan Situation. Corruption in South Asia-India, Pakistan and Sri Lanka. Edited by K M de Silva, G H Peiris and S W R de A Samarasinghe. Kandy: International Centre for Ethnic Studies, 277-302.

Sandholtz, W., \& Keotzle, W. (2000). Accounting for Corruption: Economic Structure, Democracy, and Trade. International Studies Quarterly, 44, 31-50. https://doi.org/10.1111/0020-8833.00147

Shakeel, M. (2010). Public Procurement and Corruption in Bangladesh Confronting the Challenges and Opportunities. USA: American Society of Public Administration.

Shalizi, H. (2014). Judge toughens Jail Terms in Kabul Bank Scandal, Freezes Karzai Brother's Assets. Reuters, November 11, 2014, available at http://www.reuters.com/article/2014/11/11/us-afghanistan-bank-idUSKCNOIV1X020141111

Shepler, D. (2015). Jim Gourley, Wanna Know Why We Lost in Afghanistan? Foreign Policy, February 11, 2015, available at

https://foreignpolicy.com/2015/02/11/jim-gourley-wannaknow-why-we-lost-in-afghanistan-failure-on-human-terrai $\mathrm{n} /$

Shleifer, A., \& Vishny, R.W. (1993). Corruption. Quarterly Journal of Economics, 108, $599-617$. https://doi.org/10.2307/2118402

Shrestha, P. M. (2007). Corruption in Infrastructure Provision and Service Delivery at the Municipal Level in Nepal. Kathmandu: Water, Engineering and Development Centre.

Sinah, A. C. (2001). Himalayan Kingdom of Bhutan: Tradition, Transition, and Transformation. New Delhi: Indus.

Sissener, T. K. (2001). Anthropological Perspectives on Corruption. Michelsen: Institute Development Studies and Human Rights.

Syful, I. (2012). Small Businesses Pay Price in Bangladesh's Biggest Loan Scam. http://www.trust.org/trustlaw/news/detail.dot?id=f5ef1761- 017e-42d6-8132-facaeb9248fc

Taghavi, M., Nikoomaram, H., \& Tootian,S. (2011). Comparing Impact of Administrative Corruption on Economic Growth in Developing Countries. International Journal of Management and Business Research, 2, 93-98, Spring 2011 C IAU.

Tanzi, V., \& Davoodi, H. (1997). Corruption, Public Investment, and Growth. IMF Working Paper, 97(139), 1-23. 
https://doi.org/10.5089/9781451929515.001

Torabi, Y. (2012). The Growing Challenge of Corruption in Afghanistan. (San Francisco: The Asia Foundation, 2012), available at https://asiafoundation.org/resources/pdfs/ FNLcorruptionchapterOccasionalPaperJuly30.pdf

Treisman, D. (2000). The Causes of Corruption: A Cross National Study. Journal of Public Economics, 76(3), 399-457. https://doi.org/10.1016/S0047-2727(99)00092-4

Ura, K., Alkire, S., Zangmo, T., \& Wangdi, W. (2012). An Extensive Analysis of GNH Index. Thimpu, Bhutan: Center for Bhutan Studies. Available online at, http://www.grossnationalhappiness.com

Uslaner, E. (2004). Trust and Corruption. Corruption and the New Institutional Economics. Edited by Johann Graf Lambsdorf, Markus Taube, and Matthias Schramm. London: Routledge.

Voyer, P., \& Beamish, P. (2004). The Effect of Corruption on Japanese Foreign Direct Investment. Journal of Business Ethics, 50(3), 211-224. https://doi.org/10.1023/B:BUSI.0000024737.57926.bf

Wadhwa , S. C. (2000). Maldives. Noonhu Atoll Credit Community Fund: Micro Finance Project for Income Generating Activities.

Walsh, D. (2014). At Afghan Border, Graft Is Part of the Bargain. The New York Times, November 11, 2014, available at http://www.nytimes.com/2014/11/12/world/asia/in-afghanistancustoms-system-corruption-is-part-of-the-bargain.ht $\mathrm{ml}$

Wangchuk, T. (2004). The Middle Path to Democracy in the Kingdom of Bhutan. Asian Survey, 44(6). https://doi.org/10.1525/as.2004.44.6.836

Wedeman, A. (2002). Development and Corruption: the East Asian Paradox. Political Business in East Asia. Edited by E. T. Gomez. London: Routledge, 34-61. https://doi.org/10.4324/9780203166338_chapter_1

Wei, S. (2000). "How Taxing is Corruption on International Investors?" Review of Economics and Statistics, 82(1), 1-11. https://doi.org/10.1162/003465300558533

Wei, S. (2000). Local Corruption and Global Capital Flows. Brookings Papers on Economic Activity, 2, 303-354. https://doi.org/10.1353/eca.2000.0021

Wickramasinghe, N. (2001). Civil Society in Sri Lanka: New Circles of Power. New Delhi: Sage Publications.

Winderl, T. (2004). Bhutan - the Making of a Modern State. Available at http://www.winderl.net/countries/bhutan/Bhut an\%20-\%20Towards\%20a\%20Modern\%20State.pdf

Wu, S. Y. (2006). Corruption and Cross-border Investment by Multinational Firms. Journal of Comparative Economics, 34(4), 839-856. https://doi.org/10.1016/j.jce.2006.08.007

Yolles, M. (2008). A Social Psychological Basis of Corruption and Sociopathology. Economic Corruption: Detection, Costs and Prevention. Edited by Federico N. New York: Nova Science Publishers, Inc.

You, J. S., \& Khagram, S. (2004). Inequality and Corruption. Working Paper RWP04-001, Kennedy School of Government, Harvard University, Cambridge MA. https://doi.org/10.2139/ssrn.489823

Zhao, J., Kim, S., \& J. Du. (2003). The Impact of Corruption and Transparency on Foreign Direct Investment: An Empirical Analysis. Management International Review, 43(1), 41-62.

\section{Reports}

ANSA. Viewed 26 February, 2014 http://southasia.oneworld.net/Files/building-a- responsive governance-Ecosystem.

Baseline Study on Corporate Social Responsibility Practices in the Maldives. (2010). Maldives: Ministry of Economic Development, FJS, MNCCI, \& UNDP .

Bribery and Corruption: Ground Reality in India. India: Fraud Investigation \& Dispute Services, EY \& FICCI, 2014.

Business Anti-corruption Portal, Bangladesh Country Profile (2012), http://www.business-anti-corruption.com/countryprofiles/south-asia/bangladesh/snapshot/ Bertelsmann Foundation, Bangladesh country report 2012.

Civil Society Forum Report. (2010). Maldives: MOHA.

Rapid Assessment of the Employment Situation in the Maldives. (2009). Maldives: Human Rights Commission of the Maldives, HRCM.

Summary Report on Women in Public Life in the Maldives: A Situation Analysis. (2010). Maldives: UNDP.

Transparency International Secretariat (2012). South Asia: Corruption Plagues Daily Life. Retrieved from 
http://www.transparency.org/news/pressrelease/20120116_south_asia

Withdrawal of the Serious Criminal Cases and Impunity in Nepal. (2010). Nepal: FORHID.

\section{Copyrights}

Copyright for this article is retained by the author(s), with first publication rights granted to the journal.

This is an open-access article distributed under the terms and conditions of the Creative Commons Attribution license which permits unrestricted use, distribution, and reproduction in any medium, provided the original work is properly cited. 